\title{
The role of intergovernmental relations in response to a wicked problem: an analysis of the COVID-19 crisis in the BRICS
}

\section{countries}

\author{
Jose A. Puppim de Oliveira 123 \\ Alexey G. Barabashev ${ }^{4}$ \\ Christopher Tapscott ${ }^{5}$ \\ Lisa Ingrid Thompson ${ }^{5}$ \\ Haoqi Qian ${ }^{3}$ \\ 1 Fundação Getulio Vargas / Escola de Administração de Empresas de São Paulo, São Paulo / SP - Brazil \\ 2 Fundação Getulio Vargas / Escola Brasileira de Administração Pública e de Empresas, Rio de Janeiro / RJ - Brazil \\ 3 Fudan University / Institute for Global Public Policy, Shanghai - China \\ ${ }^{4}$ National Research University / Higher School of Economics, Moscow - Russia \\ ${ }^{5}$ University of Western Cape, Bellville - South Africa
}

Globally, policy environments have become increasingly more complex with the growth in the number of wicked problems, such as that posed by the COVID-19 pandemic. In their response to these problems, public administrations have, from necessity, become heavily reliant on their intergovernmental relations systems, as the challenges posed generally require multilevel responses. This paper analyzes the role of intergovernmental relations in shaping the responses of the BRICS countries when confronted with COVID-19. We develop an analytical framework to understand the dynamics of intergovernmental relations in these countries. Based on this we assess the capacity of the state and political systems to manage intergovernmental relations and ensure effective responses to the COVID-19 crisis. This framework is based on an analysis of three dimensions of the policy domain: the political and state system, formal and informal institutions, and the political alignment between them. Whilst state and political systems were found to be instrumental in formulating an immediate response to the crisis, informal institutions and political processes also played a prominent role in determining the extent to which strategies were implemented, particularly in countries that are more decentralized. Countries lacking the robust formal institutions needed to facilitate intergovernmental relations and to ensure swift policy responses, tend to deliver ineffective and inefficient results when confronted with wicked problems.

Keywords: COVID-19; intergovernmental relations; institutions; wicked problem; BRICS.

\section{0 papel das relações intergovernamentais em resposta a um problema perverso: uma análise da crise da COVID-19 nos países do BRICS}

Políticas públicas para solução de problemas perversos (wicked problems), como a crise da COVID-19, têm sido dificultadas devido à complexidade dos ambientes institucionais em que elas acontecem. Esses problemas também requerem cada vez mais coordenação multinível, dando um papel fundamental às relações intergovernamentais. Este artigo analisa esse papel na resposta dos países do BRICS (Brasil, Rússia, Índia, China e África do Sul) à crise da COVID-19. Foi desenvolvido um arcabouço analítico para entender a dinâmica dessas relações intergovernamentais, que foi usado para avaliar a capacidade do estado e dos sistemas políticos para dar respostas efetivas à COVID-19. O arcabouço é baseado em três dimensões: o sistema político e do estado, as instituições formais e informais, e o alinhamento político entre os níveis de governo e a administração pública. Apesar da importância dos sistemas políticos e de estado, as instituições informais e os processos políticos foram instrumentais para definir e implementar as estratégias de combate à COVID-19, principalmente nos países mais decentralizados. Países sem instituições formais robustas para facilitar as relações intergovernamentais tendem a oferecer resultados ineficientes e não-efetivos em termos de políticas públicas para atacar problemas perversos.

Palavras-chave: COVID-19; relações intergovernamentais; instituições; problema perverso; BRICS. 


\title{
El papel de las relaciones intergubernamentales en respuesta a un problema perverso: un análisis de la crisis de COVID-19 en los países BRICS
}

\begin{abstract}
Las políticas públicas para resolver problemas perversos (wicked problems), como la crisis de COVID-19, se han visto obstaculizadas por la complejidad de los entornos institucionales en los que ocurren. Estos problemas también requieren cada vez más una coordinación multinivel, lo que hace que las relaciones intergubernamentales jueguen un papel fundamental. Este artículo analiza ese papel en la respuesta de los países BRICS (Brasil, Rusia, India, China y Sudáfrica) a la crisis de la COVID-19. Se desarrolló un marco analítico para comprender la dinámica de estas relaciones intergubernamentales, que se utilizó para evaluar la capacidad del estado y de los sistemas políticos para brindar respuestas efectivas a la COVID-19. El marco se basa en tres dimensiones: el sistema político y estatal, las instituciones formales e informales y la alineación política entre los niveles de gobierno y la administración pública. A pesar de la importancia de los sistemas políticos y estatal, las instituciones informales y los procesos políticos fueron fundamentales para definir e implementar estrategias para combatir la COVID-19, especialmente en los países más descentralizados. Los países sin instituciones formales sólidas para facilitar las relaciones intergubernamentales tienden a ofrecer resultados ineficientes e ineficaces en términos de políticas públicas para abordar problemas perversos.
\end{abstract}

Palabras clave: COVID-19; relaciones intergubernamentales; instituciones; problema perverso; BRICS.

\section{INTRODUCTION}

The advent of the COVID-19 pandemic around the world has necessitated an unprecedented response from public administrations, at all levels of the governing hierarchy, in order to respond rapidly to the crisis on a variety of different fronts. In its spread and degree of contagion the pandemic is very different from previous viral outbreaks, such as SARS (Heymann \& Shindo, 2020; World Health Organization [WHO], 2020) and there was little past experience to draw on. In its initial phase COVID-19 appeared to present a public health threat which could be contained medically. However, as the virus spread in became increasingly evident that it posed a multi-sectoral challenge which threatened the economy, social protection, transport, and education amongst others. Sub-national administrations, already under-resourced in many countries, became particularly challenged when called upon to respond to the crisis under conditions of great uncertainty. With the possible exception of China, the capacity of subnational governments amongst the BRICS states is generally highly variable and this applies to their health systems in particular. The state of Acre, which is situated in the poor northern parts of Brazil, for example, has 0.9 Intensive Care Unit (ICU) beds per 10,000 inhabitants compared to Rio de Janeiro, which proportionally has more than three times this number (Agência Nacional de Saúde Suplementar [ANS], 2018). The capacity of subnational governments to respond to policy challenges posed by wicked problems is heavily dependent on intra and intergovernmental relations (Pierre, 1999). In Russia, imbalances in the geographic distribution of ICU beds have decreased significantly since the onset of the pandemic. Towards the end of 2019 there had been around 20000 ICU beds which were largely concentrated in the urban areas, but by May 2020 this number had increased to 130000 ICU beds which are now more evenly distributed around the country. This was due to a massive hospital construction program funded by the Federal Government in regions across Russia. Effective interaction between national and sub-national levels of government is of crucial importance in bridging the constitutional autonomy and capacity gaps 
between so that they are able tackle wicked problems such as COVID-19 (Paquet \& Schertzer, 2020) in a concerted fashion (Agranoff, 2004; O’Toole \& Christensen, 2013). Other stakeholders in society, such as the private sector and civil society organizations (CSOs), also have an important role to play in building public awareness and in overcoming political divisions that might constrain collective responses to major policy challenges (Agranoff, 2011; Davenport \& Prusak, 2000). In this context, a key governance question relates to the way in which intergovernmental cooperation and support aid or impede a state's response to wicked problems.

This paper examines how institutions and organizational mechanisms that support intergovernmental relations have shaped responses to COVID-19 in the five BRICS countries (Brazil, Russia, India, China and South Africa). It looks at the role played by intergovernmental relations in formulating rapid policy responses to the threats presented by a wicked problem. Viewed through the lens of intergovernmental relations and institutional building, the research evaluates responses of the BRICS states from the perspective of context, design, implementation and outcomes.

The principal contribution of the paper is in the development of an analytical framework to assess how intergovernmental relations in developing countries, and more specifically in the BRICS states, influence efforts to overcome wicked problems. Each of the contributing authors compiled data for one of the BRICS states, using local networks and knowledge and augmented with secondary data generated through the internet ${ }^{1}$. A set of 52 questions relating to the different ways in which each country responded to COVID-19 was collected by the authors and those related to intergovernmental relations are summarized in Box 1. The study is a cross country analysis, rather than a comparative one, which looks at the different ways in which the five BRICS states have responded to COVID-19 and, as the pandemic is still underway, it must be noted that the information presented pertains only to the end of August 2020.

The BRICS countries have diverse forms of state and equally diverse systems of intergovernmental relations. China and South African have unitary systems (although the later embodies elements of federalism in its constitution), while Russia, India and Brazil are federal states which have devolved parts of the decision making authority to lower echelons of government. This diversity in the forms of state in the BRICS countries provides an opportunity to analyze how different types of intergovernmental relationships have been able to respond to the crisis precipitated by COVID-19 and to assess how this has progressed over time. This analysis of the BRICS states provides some interesting insights although it remains too soon to draw any definitive conclusions about how influential their intergovernmental systems have determined the results in the combat of the spread of COVID-19 and preservation of their economies, because the pandemic has yet to fully run its course.

Each of the BRICS countries have their own distinctive configuration of administrative and political autonomy and different degrees of organizational capacity and responsibility are assigned to different levels of government. These organizational configurations influence the way in which states respond to the policy challenges which confront them. In India and Brazil, for example, front line medical responses to COVID-19, are mostly made at the level of state and municipal government whilst overall responsibility for health policy and health protocol falls under the central government. In contrast, the

${ }^{1}$ This data was originally collected in April and May 2020 but was updated in August and September 2020. 
management of health in Russia and China is controlled by the central government, whilst in South Africa the responsibility is shared between the national and provincial governments with very little involvement of local government. As a consequence, the BRICS countries responded very differently to the onset of COVID-19 and the role of their respective systems of intergovernmental relations in shaping these responses was equally varied (Tang \& An, 2020). Notwithstanding these differences, however, our research underscores the importance of cooperative forms of intergovernmental relations in formulating coordinated and swift responses to the pandemic.

\section{INTERGOVERNMENTAL RELATIONS AND POLICY RESPONSES TO WICKED PROBLEMS}

Intergovernmental relations are key to our understanding of the formulation of public policy and state responses to complex public problems (Agranoff, 2004; Phillimore, 2013). This is because the resolution of wicked problems requires much stronger coordination between different tiers of government and civil society than more conventional policy formulation although, here too, it remains important. The challenges posed by wicked problems range from global health pandemics, such as COVID-19 (Paquet \& Schertzer, 2020; Tang \& An, 2020), to the integration of mass waves of migrants (Adam \& Hepburn, 2019), global warming, and regional integration, all which require a multi-level governance response (Happaerts, Schunz \& Bruyninckx, 2012; Peters \& Pierre, 2001; Puppim de Oliveira, 2019). This is notwithstanding the fact that the recent fiscal crises suffered by a number of countries have led to a greater centralisation of decision making at diminution of the autonomy of sub-national governments (Mello \& Jalles, 2019). Effective intergovernmental relations, in contrast, can serve to integrate the efforts of different tiers of government and can increase the capacity of a state to respond to multi-level challenges more effectively (Balme \& Ye, 2014; McGuire \& Silvia, 2010). The literature on this topic, nevertheless, remains limited and many questions on how more effective intergovernmental relations might be achieved remain unanswered (Hegele, 2018; Kincaid \& Steinberg, 2011; O’Toole \& Meier, 2004; Rhodes, 2018). Efforts to understand and promote better intergovernmental coordination in practice have also been disappointing, as evident in the recent history of the United States (Kindcaid \& Steinberg, 2011; Schneider, 2008) and particularly as demonstrated in government responses to the COVID-19 crisis (Tang \& An, 2020).

We identified three key factors in the literature that affect the way in which intergovernmental relations influence responses to wicked problems. Firstly, the form of the state (unitary or federation, and levels of government) and the political system (authoritarian or liberal democracies) in place determine the type of intergovernmental relations which exist in a particular order of government. Discussions in the literature include those on the features of federal arrangements and the kinds of intergovernmental relations to which they give rise (Rhode, 2018). Secondly, the type of intergovernmental relations institutions and practices in place, which may be formal or informal in nature (North, 1990). In many instances, cooperation between different levels of government is urgently required but there are no formal institutions or mechanisms in place to facilitate intergovernmental cooperation, and this is left to informal processes and institutions which can take time to negotiate (Phillimore, 2013). The increasing complexity of policy problems can also challenge the resilience of informal institutions and their capacity to deliver effective policy responses. Thirdly, the role played by politics in building or obstructing intergovernmental relations. Political differences can lead to intractable situations where 
no agreement on cooperation can be reached between different levels of government, particularly in contexts where national politics are polarized (Conlan, 2017; Ouverney \& Fleury, 2017). In that respect, it is common for different levels of government to blame each other for the failure of a policy that may have been implemented in an area of overlapping or disputed jurisdiction (Stratton, 1989; Tang \& An, 2020). Conversely, in instances where functional intergovernmental systems are in place, political rivalry can spur competition between levels of government to achieve better responses to a particular policy challenge (Fiszbein, 1997), and, thereby, to demonstrate their superior governance skills to their respective constituencies.

Applying the three determining factors identified above, this paper develops a framework for analyzing the ways in which intergovernmental relations shape policy responses to a wicked problem. The dynamics of intergovernmental relations are examined in the context of state responses to the COVID-19 crisis in the five BRICS countries.

\section{INTERGOVERNMENTAL RELATIONS AND COVID-19 IN THE BRICS}

The countries which make up the BRICS consortium, Brazil, Russia, India, China and South Africa, are a heterogeneous group of large medium-income states which control a substantial portion of the world's economy and have growing power in the global arena. Together they cover approximately $26 \%$ of the Earth's land mass (39.1 million square $\mathrm{km}$ ), accommodate $42 \%$ of the world's population (3.1 billion inhabitants), and generate 33\% of the global economy in GDP per capita PPP (USD 44.1 trillion) (International Monetary Fund [IMF], 2019; United Nations Department of Economic and Social Affairs [UNDESA], 2019). In addition to their size, they are also all regional powers with influence in their respective geo-political domains.

Political and administrative systems in the BRICS countries, as indicated, are very different from each other (Barabashev \& Klimenko, 2017; Jing, 2017; Mathur \& Mathur, 2017; Puppim de Oliveira, 2017; Tapscott, 2017). Box 1 provides a summary of the different intergovernmental relations systems in the BRICS and their varied responses to COVID-19. While China and South Africa, as discussed, have unitary systems, Brazil, Russia and India are federal governments in which different degrees of autonomy are constitutionally assigned to the state governments. However as the BRICS countries have multi-level governments there is some degree of decentralized decisions making and policy formulation in all five, and this calls for close coordination between them in formulating and implementing public policies such as those for health and education. Taken together, the BRICS states have more than one million subnational governments (China alone has more than 750,000 of these entities) with considerable diversity between them. Despite its status as a centralized state, there has been a gradual but steady process of decentralization underway in China since the opening up of the policy making process in 1978 and an emphasis on effective intergovernmental relations is an important component of the Chinese model of development (Cai \& Treisman, 2006; Jing, 2017).

Responses to the onset of COVID-19 were quite different among the five countries (see Figure 1 and Box 1 for a summary of the situation and levels of response). China was the first country to be hit by the virus and this occurred in Wuhan province in the end of 2019. Despite an uncertain start, which included a lack of clarity and poor communication on the extent of the threat posed by the outbreak of the virus in Wuhan, the central government mounted a swift and coordinated response 
which included the isolation and quarantining of people living in several contagion hot spots during the Chinese New Year (Kummitha, 2020). This contained the spread of cases to other parts of the country, but it also came at a high cost to the economy, which only began to recover in May 2020. Strict containment policies also continue to be enforced even though the very few cases were recorded in August 2020. China's quick response can be ascribed to the fact that it was coordinated and steered by a multi-sectoral cooperation platform which was established in January 2020 to combat the outbreak of COVID-19. Called the Joint Prevention and Control Mechanism of the State Council (JPCMSC), this structure is responsible for coordinating the activities of the 32 sectors which fall under its aegis.

The remaining four BRICS countries responded to the onset of the pandemic with varying degrees of urgency. India began controlling the entry of people from China in January 2020 and recorded its first case of COVID-19 in that month. A hard lockdown was imposed on 24 March and, at least in the early months, this was strictly enforced. However, as in South Africa, the efficacy of the measures introduced by the federal and state governments were constrained by the wide disparity in the quality of health care facilities across the country and this include access to hospital beds and ventilators. It was also made difficult by fact that large numbers of people live in densely crowded informal settlements were effective social distancing is impossible. Thus, despite some containment, the virus has continued to spread and India had the second highest number of COVID-19 cases in the world in the end of August 2020 (see Figure 1).

In Russia, the spread of the pandemic gained momentum in February 2020 but containment measures were only introduced in early March (and then mostly as recommendations in what was considered to be a "soft form" of containment). This was followed by a strict lockdown instituted on March $30^{\text {th }}$. Responsibility for containment of the disease was delegated to the regional governments and this led to a variable and uncoordinated subnational response to the crisis (which varied from strict measures in Moscow, to almost no restrictions in far eastern regions). The response in Brazil was even slower, and the world-renowned Carnival was allowed to go ahead at the end of February despite evidence that the pandemic was well on its way (the first case of COVID-19 in the country was in fact confirmed during the Carnival, though there are signs of more cases earlier on). The federal government opted not to impose any form of quarantine and left decisive containment measures to states and local governments and these came into effect in mid-March. However, just two months after the quarantine measures (which were of variable effectiveness) had been imposed, the central government began to put pressure on regional government to ease restrictions and open up the economy. In this context of policy uncertainty the disease spread rapidly and by May the situation was out of control. There was little testing or tracing of those infected by COVID-19, hospital services were overwhelmed, the virus spread into the interior of the country and the number of deaths grew rapidly such that by the beginning of September 2020 Brazil had the second largest number of confirmed deaths of COVID-19 after the United States, with little sign of the disease abating.

In South Africa the central government responded decisively to the onset of COVID-19 and declared a national disaster on 15 March 2020, just 10 days after the first case had been diagnosed in the country. This was followed by a hard lockdown on $26 \mathrm{March}$, a reduced version of which still remains in place in September 2020. The National Disaster Act, which was invoked to declare COVID-19 a national emergency, provides sweeping powers to the central government and these have been used to 
direct national policy responses throughout the pandemic. A National Command Council, chaired by the President and comprised of 19 cabinet ministers, is responsible for coordinating the responses of different sectors of the state, and there is regular consultation with other levels of government. Unlike, arrangements in India, the South African government was able to shift resources from less severely infected areas to identified hotspots and mobilised the national defence force to enforce early stages of the lockdown. From the outset, the government stressed that its focus was on saving lives and its swift response bought time for the medical services to prepare for the onslaught of the disease. Thus, although South Africa has one of the highest incidences of COVID-19 in the world, the death rate per capita (despite evident under-reporting) is also one of the lowest. National statistics also reveal that the disease has passed its peak and infections rates and deaths are in decline in mid-September 2020. The government, however, has faced criticism for the fact that the protracted lockdown has seriously damaged the economy which has fallen into recession in the midst of mounting government debt.

Intergovernmental relations played a key role, whether positively or negatively, in shaping national responses to the multi-dimensional challenges posed by the COVID-19 in all of the BRICS countries. In the section which follows we discuss how different facets of intergovernmental relations influenced government responses to the crisis using the framework based on section 2 .

\section{DISCUSSION: UNDERSTANDING THE DYNAMICS OF INTERGOVERNMENTAL RELATIONS, TO RESPOND TO THE COVID-19 CRISIS}

All five countries have systems of multi-level government albeit it with different structures, responsibilities and powers. As in other states, intergovernmental relations serve as a mechanism to coordinate public policy responses by ensuring that appropriate authority, finance, information, and technical resources are allocated to the levels of government responsible for their execution. From our analysis of the BRICS states it is possible to identify the three factors recognized in the literature (section 2) as being key to understanding the dynamics of intergovernmental relations and the degree to which multi-level governments are capable of forging a coordinated and effective response to the COVID-19 crisis. These three determining factors are the political and state systems, formal and informal institutions, and political alignment, each of which will be analyzed below.

\subsection{Political and State Systems}

The differences in political systems (authoritarian versus liberal democracy) and form of the state (unitary versus federation) influence intergovernmental relations and, consequently, policy responses (Agranoff, 2004; Elazar, 1987; Jalal, 1995; Tang \& An, 2020). In unitary governments, such as those in China and South Africa, or in centralized federal systems, as in Russia, the dominance of a single party across different levels of government make political alignment and informal processes in intergovernmental relations less relevant in policy formulation. This is because central governments can generally exercise their constitutional authority and political power to override subordinate levels of government should they wish to do so. Even though responsibility for the provision of health services in South Africa is largely shared between central and provincial government, when confronted by the COVID-19 crisis, the central government was able to move decisively in imposing a hard lockdown. 
It has also continued to steer state responses to the pandemic throughout and has intervened when provincial governments have been seen to be failing in their execution of policy. In Russia, the central government initially devolved key decision making on COVID-19 to the regions, but as conditions worsened in May there was a reversion to a more coordinated intergovernmental form of decision making, shared between the federal and regional governments. The experience of Russia also suggests that excessive centralization is not necessarily the most effective way of responding to a national crisis which requires the transfer of resources to the local level and effective communication between multiple sectors. In more decentralized administrative systems, such as those in Brazil and India, effective responses depend heavily on the capacity of subnational governments. In India, the states control health systems and exercise significant influence in responding to COVID-19 responses. In contrast, despite the fact Brazil is a decentralized federal state, financial control remains highly centralized and the central government wields certain authority in its dealings with subnational government (Couto \& Absher-Bellon, 2018). Consequently, the responses of subnational units consequently to COVID-19 were uneven and erratic, particularly as the federal government failed to develop a coherent national response to the pandemic.

Political systems can influence the way in which policies are adopted across different levels of government, particularly when they involve sensitive issues such as the restriction of political freedoms or the perceived invasion of personal privacy. Political systems, consequently, were of importance in influencing state responses to COVID-19 and the manner in which they were implemented. Of the five BRICS countries, three are constitutional democracies countries with freedom of the press and internationally monitored elections (Brazil, India and South Africa), and two (Russia and China) have more centralized political systems with tight state-control over information and the media. The latter two countries were able to rapidly develop systems to test, track, and trace individuals who are potentially infected by COVID-19. They did so by surveilling private individual information (on cellphones, and other on-line platforms) which in other countries, particularly those with Western style democracies, would be legally and socially difficult if not impossible to collect (Kummitha, 2020). China and Russia, however, were able to develop a more technological based approach to tracking COVID-19 and did so without much political resistance. China, in particular, was able to quickly introduce a system to track, trace and control isolation using already existing government information systems which collect individual information through webcams and Apps such as WeChat. As soon as an individual was confirmed to have COVID-19, it was relatively easy to trace her whereabouts through her personal information by, for example, by tracking her financial transactions and mapping the shops she had visited in the preceding few days. The Ministry of Industry and Information Technology established a centralised big data analysis platform to integrate the data of China's three biggest telecom operators. Based on this integrated platform, a specialized mobile app was developed which records the movements of individuals and which has to be produced on demand (so called "Health QR code"). The individual QR code is a type of health passport which is required in order to enter certain localities and some public places. During the lockdown control measures in some regions of Russia, particularly in the large cities, were especially tight due to the introduction of a system of electronic passes. Amongst the measures used to track and control the movement people were CCTV cameras equipped with face recognition technology and data derived 
from taxi companies. Individuals who were diagnosed with mild symptoms or were known to be asymptomatic were contacted telephonically and instructed to stay at home. A lockdown index of human movement was published daily and in Moscow this was reflected on a five-point scale which ranged from 1 , crowded streets, to 5 , streets which were empty. The movement of people was controlled by accessing smart phone GPS systems and in the issuing of public transport tickets. Although the movement of people in Brazil, India or South Africa was restricted during the lockdown, surveillance of the type introduced in China and Russia would not have been permissible or possible had it been contemplated. This was due to the fact that their governments lacked the constitutional authority to access to private information and attempts to do so would likely have been challenged by civil society organizations and the political opposition. It is also the case that in Brazil, India and South Africa governments lacked the technological capacity to conduct broad scale surveillance and were further constrained by the fact that many people do not own smart phones. Nevertheless, Russia and China were quick to build up their capacity to conduct large scale testing in all levels of government and this enabled early detection of infections, and the isolation of communities or localities were there was seen to be an increase in the incidence of COVID-19. In Brazil, in contrast, even the relatively uncontentious issue of mass testing was disputed on political lines.

\subsection{Formal and informal Institutions}

Formal and informal institutions and processes assist in shaping intergovernmental relations and are important in determining policy decisions (Phillimore, 2013). In the democratic federal states, formal institutions are usually delineated by the constitution and other legislation, but informal processes are nevertheless important in negotiating agreements and in overcoming issues of contestation. Some federal constitutions, such as that of India which derives from the British colonial administration (Fry, 1999), clearly define the respective jurisdictions and responsibilities of central and subnational governments, notwithstanding the fact that state governments operate with a significant degree of autonomy in formulating and implementing policy (Fenna, 2012). As a consequence, despite political differences between the federal government controlled by Narenda Modi's BJP party and states controlled by a variety of opposition parties, responses to COVID-19 were not, in most instances, constrained or paralyzed by intergovernmental conflict. However, where the responsibilities of different echelons of government are not constitutionally defined and working relationships between and within them are not further made explicit in legislation, the risk of discord and conflict is likely to be high. Such is the case in the tri-partite health system in Brazil where, in the absence of clearly legislated boundaries, there is a reliance on informal processes to negotiate a coordinated response to crises. Reaching consensus through these informal processes can take time and resources and the outcome is not always predictable, and this can lead to further conflicts that prevent coordination. In Brazil, the provision of health services is divided between all three levels of government, although the central government retains control over the purse strings. There are, however, no clearly legislated criteria for the distribution of federal resources to the state and municipal health services in the event of a national emergency. This led to unpredictable, and often negative, outcomes when the national health system was confronted by the COVID-19 pandemic. In Russia the COVID-19 crisis led to changes in the powers and functions constitutionally assigned to subnational governments, although 
it did not result in actual constitutional reform. In the Russian federal system the central government exercises considerable control over regional governments (Barabashev \& Klimenko, 2017) and has the constitutional power to override decisions made by lower levels of governments. However, faced with the rapid spread of the Corona virus it became necessary to devolve national functions and resources to lower levels of governance (regional, municipal) in order to ensure that measures were implemented effectively at the local level. What emerges from this discussion is that the responsibilities and jurisdictional boundaries of different levels of government, together with their budgetary entitlements, need to be clearly defined and legislated if an intergovernmental relations system is to be effective in combating a wicked problem such as that created by the COVID-19 pandemic.

\subsection{Political alignment}

Political alignments play a pivotal role in shaping intergovernmental relations and in determining the effectiveness of policy responses. This is because political systems mediate public policy decision making and can either assist or constrain development of the trust and social cohesion necessary to manage a public crisis like COVID-19. The implementation of public policy frequently requires collaboration with a variety of civil society stakeholders and coordination between different sectors and levels of governments (McGuire \& Silvia, 2010). Formal institutions and mechanisms exist to define these responsibilities, but, constitutionally, most subnational governments are granted some political discretion in determining the type of cooperation they will agree to. This would include the conditions under which they might provide services to, or accept assistance from, the national government since these might come with political strings. In India, for example, the national government offered technical support to states in the fight against COVID-19 but some states, such as the opposition run Kerala State, opted to use its own technical expertise, developed over the years, combat the disease. In contexts where two levels of government are controlled by the same political party, policy coordination is generally far easier (Nice, 1987; Souza, 1997; Wright, 1990). This is because higher levels of government are able to exercise a greater degree of discretion in that they generally have more power and resources at their disposal than subnational entities. Political relations, thus, are critical in determining the type of cooperation that prevails between levels of governments.

In four of the BRICS countries, cooperation between the different levels of governments in combating COVID-19 was not significantly influenced by politics. This was either because political alignment existed among most levels of government (as was the case in China and Russia, despite some tactical disagreements in the latter), or because opposition parties set aside their political differences for the common good of combating the virus (South Africa and India). In Brazil, however, politics played an major role in shaping the government's response and was largely responsible for the uncoordinated response between different levels of government. This began with a series of disagreements between the president and state governors over the approach which should be adopted in combating COVID-19. There were also instances of conflict between all three levels of government (federal, state and municipal), where the president, the governor and the mayor clashed over policy and the matter had to be resolved in court. Further conflict also occurred within the federal and state governments and on one occasion Brazil had three different health ministers in the space of one month. In several states health secretaries were replaced because they held views on managing 
the crisis with differed from that of the governors. The divisive politics and fragmented political system of Brazil have constrained efforts to implement a coordinated response to COVID-19. From the experiences of the BRICS states is evident that an effective system of intergovernmental relations should be capable of mediating administrative disputes and of ensuring the coordination necessary to respond to a crisis regardless of ongoing tensions and conflicts within the polity.

\section{CONCLUSION}

There are a number conclusions that can be drawn from an application of the analytical framework developed above to assess the role of intergovernmental relations in state responses to wicked problems such as COVID-19. The first is that there was no silver bullet in the approaches adopted by the BRICS states to combat COVID-19 and their responses varied in their form and effectiveness. In that respect, public administration systems tend to have an equifinality tenet (Arundel, 2017), implying that an effective response can be achieved through a variety of different combinations of intergovernmental relations, depending on the capacity of subnational governments. Second is that, irrespective of the country or form of state, the effectiveness of their COVID-19 responses is dependent on the effectiveness of their intergovernmental relations systems, since all have subnational government which are needed in efforts to manage the pandemic. Since containment of the virus, and the treatment of those infected by it, is dependent on the measures implemented at grassroots level, coordination between subnational and national government is of critical importance. This is because the former generally have less resources than the central government and lack the authority to ensure coordination with sectors which fall outside of their jurisdictional domain.

Third, clarity on the roles and responsibilities of different levels of government is important in mounting a swift response to a crisis. In countries like Brazil, where health care is multi-level responsibility with over-lapping jurisdictions, there tends to be a reliance on informal relations to ensure the coordination of government efforts and this increases the risk of policy failure. Furthermore, in contexts where there is little political consensus, clearly defined intergovernmental institutions and mechanisms are essential in order to ensure that administrative systems and activities do not risk to be paralyzed by ongoing struggles in the polity.

Wicked problems, such as that created by the COVID-19 crisis, have presented new challenges to governments around the world. They have also highlighted the importance of intergovernmental relations in the design of effective responses to complex crises since these need to be multi-sectoral and multi-level in their implementation. This paper has shed light on the initial responses of the BRICS countries to the COVID-19 pandemic and the extent to these were influenced by their different systems of intergovernmental relations. However, further research on the topic is required as definitive administrative responses to such crises has yet to be found. 


\section{REFERENCES}

Adam, I., \& Hepburn, E. (2019). Intergovernmental relations on immigrant integration in multi-level states. A comparative assessment. Regional \& Federal Studies, 29(5), 563-589.

Agência Nacional de Saúde Suplementar. (2018). Medicina Intensiva no Brasil. Brasília, DF: Author.

Agranoff, R. (2004). JPART symposium introduction: Researching intergovernmental relations. Journal of Public Administration Research and Theory, 14(4), 443-446.

Agranoff, R. (2011). Federalist No. 44: What Is the Role of Intergovernmental Relations in Federalism? Public Administration Review, 71, s68-s77.

Arundel, A. (2017). Rethinking the effect of risk aversion on the benefits of service innovations in public administration agencies. Research Policy, 46(5), 900-910.

Balme, R., \& Qi Y. (2014). Multi-Level Governance and the Environment: Intergovernmental Relations and Innovation in Environmental Policy. Environmental Policy and Governance, 24(3), 147-154.

Barabashev, A. G., \& Klimenko, A. V. (2017). Russian governance changes and performance. Chinese Political Science Review, 2(1), 22-39.

Cai, H., \& Treisman, D. (2006). Did government decentralization cause China's economic miracle? World Politics, 58(4): 505-535.

Conlan, T. (2017). Intergovernmental relations in a compound republic: The journey from cooperative to polarized federalism. Publius: The Journal of Federalism, 47(2), 171-187.

Couto, C. G., \& Absher-Bellon, G. L. (2018). Imitação ou coerção? Constituições estaduais e centralização federativa no Brasil. Revista de Administração Pública, 52(2), 321-344.

Davenport, T. H., \& Prusak, L. (2000). Working Knowledge: How Organizations Manage What They Know. Boston, Chicago: Harvard Business School Press.

Elazar, D. J. (1987). Exploring federalism. Tuscaloosa, Alabama: University of Alabama Press.

Fenna, A. (2012). Federalism and Intergovernmental Coordination. In B. Guy Peters \& J. Pierre (Eds.),
The SAGE Handbook of Public Administration (pp. 750-763). Los Angeles, CA: SAGE.

Fiszbein, A. (1997). The emergence of local capacity: Lessons from Colombia. World Development, 25(7), 1029-1043.

Fry, G. K. (1999). More than 'counting manhole covers': the evolution of the British tradition of public administration. Public Administration, 77(3), 527-540.

Happaerts, S., Schunz, S., \& Bruyninckx, H. (2012). Federalism and intergovernmental relations: The multi-level politics of climate change policy in Belgium. Journal of Contemporary European Studies, 20(4), 441-458.

Hegele, Y. (2018). Explaining bureaucratic power in intergovernmental relations: A network approach. Public Administration, 96(4), 753-768.

Heymann, D. L., \& Shindo, N. (2020). COVID-19: what is next for public health? The Lancet, 395(10224), 542-545.

International Monetary Fund. (2019). World Economic Outlook Database. Washington, DC: Author.

International Monetary Fund. (2020). IMF and COVID-19. Retrieved from https://www.imf.org/ en/Topics/imf-and-covid19/Policy-Responses-toCOVID-19\#B

Jalal, A. (1995). Democracy and authoritarianism in South Asia: A comparative and historical perspective (Vol. 1). Cambridge, UK: Cambridge University Press.

Jing, Y. (2017). Creative incrementalism: Governance reforms in China since 1978. Chinese Political Science Review, 2(1), 56-68.

Kincaid, J., \& Stenberg, C. W. (2011). "Big Questions" about Intergovernmental Relations and Management: Who Will Address Them? Public Administration Review 71(2), 196-202.

Kummitha, R. K. R. (2020, July). Smart technologies for fighting pandemics: the technoand human- driven approaches in controlling the virus transmission. Government Information Quarterly, 37(3), 101481. Retrieved from https:// doi.org/10.1016/j.giq.2020.101481

Mathur, K., \& Mathur, N. (2017). Assessing Administrative Reform in India. Chinese Political Science Review, 2(1), 40-55. 
McGuire, M., \& Silvia, C. (2010). The effect of problem severity, managerial and organizational capacity, and agency structure on intergovernmental collaboration: Evidence from local emergency management. Public Administration Review, 70(2), 279-288.

Mello, L., \& Jalles, J. T. (2019). The global crisis and intergovernmental relations: centralization versus decentralization 10 years on. Regional Studies, 54(7), 1-16.

Nice, D. C. (1987). Federalism: The politics of intergovernmental relations. New York, NY: St. Martin's Press.

North, D. (1990). Institutions, institutional change and economic performance. New York, NY: Cambridge University Press.

O’Toole, L. J., Jr., \& Christensen, R. K. (2012). American intergovernmental relations: Foundations, perspectives, and issues. Thousand Oaks, CA: CQ Press.

O’Toole, L. J., Jr., \& Meier, K. J. (2004). Public management in intergovernmental networks: Matching structural networks and managerial networking. Journal of public administration research and theory, 14(4), 469-494.

Organisation for Economic Co-operation and Development. (2020). Coronavirus Policy Response. Retrieved from https://www.oecd.org/coronavirus/ en/\#policy-responses

Our World in Data. (2020). Website. Retrieved from ourworldindate.org

Ouverney, A. M., \& Fleury, S. (2017). Polarização federativa do SUS nos anos 1990: uma interpretação histórico-institucionalista. Revista de Administração Pública, 51(6), 1085-1103.

Paquet, M., \& Schertzer, R. (2020). COVID-19 as a Complex Intergovernmental Problem. Canadian Journal of Political Science/Revue canadienne de science politique, 53, 343-347.

Peters, B. G., \& Pierre, J. (2001). Developments in intergovernmental relations: towards multi-level governance. Policy and Politics, 29(2), 131-136.

Phillimore, J. (2013). Understanding intergovernmental relations: Key features and trends. Australian Journal of Public Administration, 72(3), 228-238
Pierre, J. (1999). Models of urban governance: The institutional dimension of urban politics. Urban Affairs Review, 34(3), 372-396.

Puppim de Oliveira, J. A. (2017). Brazilian public administration: shaping and being shaped by governance and development. Chinese Political Science Review, 2(1), 7-21.

Puppim de Oliveira, J. A. (2019). Intergovernmental relations for environmental governance: Cases of solid waste management and climate change in two Malaysian States. Journal of Environmental Management, 233, 481-488.

Rhodes, R. A. W. (2018). Control and power in central-local government relations. London, UK: Routledge.

Schneider, S. (2008). Who's to Blame? (Mis) perceptions of the Intergovernmental Response to Disasters. Publius: The Journal of Federalism, 38(4), 715-738.

Souza, C. (1997). Constitutional engineering in Brazil: the politics of federalism and decentralization. New York, NY: St. Martin's.

Stratton, R. M. (1989). Disaster relief: the politics of intergovernmental relations. Lanham, Maryland: University Press of America.

Tang, S. Y., \& An, B. (2020). Comparing Emergency Responses to COVID-19: A Governance and Intergovernmental Perspective. Available at SSRN 3602172 .

Tapscott, C. (2017). South Africa in the twenty-first century: governance challenges in the struggle for social equity and economic growth. Chinese Political Science Review, 2(1), 69-84.

United Nations Department of Economic and Social Affairs. (2019). World Population Prospects 2019. Retrieved from https://population.un.org/wpp/ Download/Standard/Population/

World Health Organization. (2020). Coronavirus disease 2019 (COVID-19). Situation report, 51. Retrieved from https://www.who.int/docs/defaultsource/coronaviruse/situation-reports/20200311sitrep-51-covid-19.pdf

Wright, D. S. (1990). Federalism, intergovernmental relations, and intergovernmental management: Historical reflections and conceptual comparisons. Public Administration Review, 50(2), 168-178. 


\section{Jose A. Puppim de Oliveira}

https://orcid.org/0000-0001-5000-6265

Professor at Fundação Getulio Vargas (FGV EAESP and FGV EBAPE); Visiting Chair Professor at Institute for Global Public Policy, Fudan University. E-mail: jose.puppim@fgv.br

\section{Alexey G. Barabashev}

https://orcid.org/0000-0003-4746-7532

President of the Graduate School of Public Administration, Chair of Civil Service Department, School of Social Sciences, National Research University - Higher School of Economics. E-mail: abarabashev@hse.ru

\section{Christopher Tapscott}

Professsor at University of Western Cape. E-mail: ctapscott@uwc.ac.za

\section{Lisa Ingrid Thompson}

Professor at University of Western Cape. E-mail: 1thompson@uwc.ac.za

\section{Haoqi Qian}

https://orcid.org/0000-0001-5156-4402

Assistant Professor at Institute for Global Public Policy and LSE-Fudan Research Centre for Global Public Policy, Fudan University. E-mail: qianhaoqi@fudan.edu.cn 
RAP | The role of intergovernmental relations in response to a wicked problem: an analysis of the COVID-19 crisis in the BRICS countries

\section{APPENDIX}

\section{FIGURE $1 \quad$ COVID-19 SITUATION AND GOVERNMENT RESPONSES IN THE BRICS}

Daily confirmed COVID-19 deaths, rolling 7-day average Limited testing and challenges in the attribution of the cause of cleath means that the number of confirmed deaths may not be an accurate count of the true number of deaths from COVID-19.

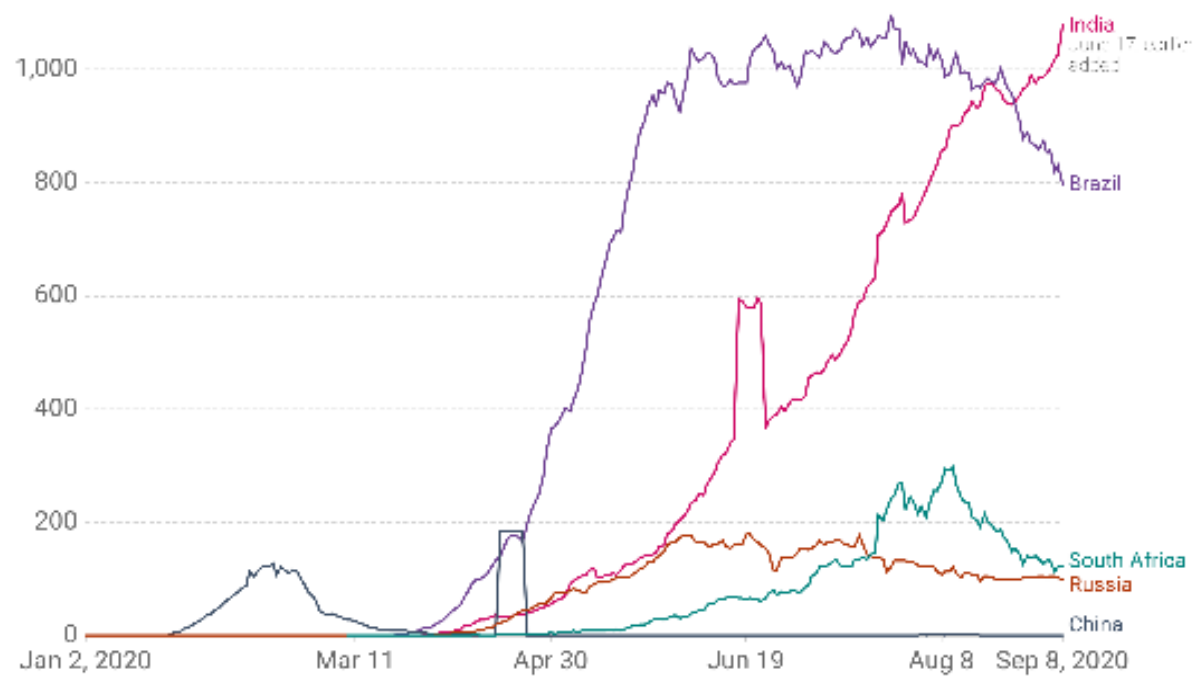

Solrce: turopean CuC - Situaticn Update Worldmide - Last updeted E September. $12: 36$ íLondon t mei

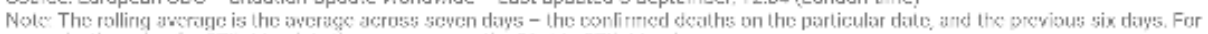

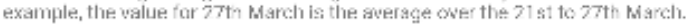

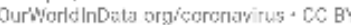

COVID-19: Government Response Stringency Index

This is a composite measure based on nine response indicators including school closures, workplace closures, and travel bans, rescaled to a value from D to $100(100=$ strictest). If policies vary at the subnational level, the index is shown as the response level of the strictest sub-region.

100

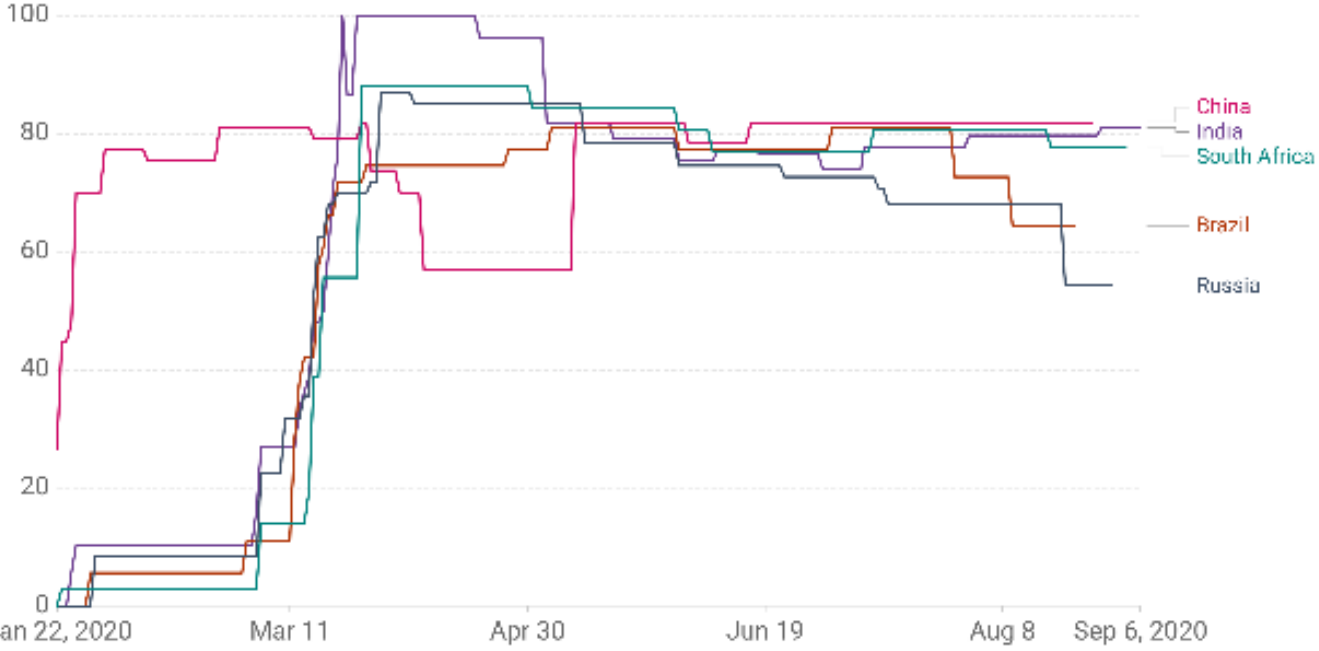

Source: Hale, Webster, Petherick, Phill ips, and Kira (2020). Oxford covld-19 Covenment Response Tracker - Last upcisted 9 September, 2:00 (London time)

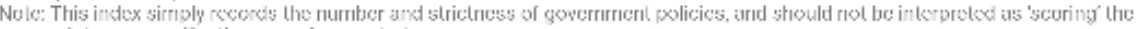
appropriakeness or ellectiveness of a country's responist.

Our'warldinuata org; coranavirus . Ec th 
RAP | The role of intergovernmental relations in response to a wicked problem: an analysis of the COVID-19 crisis in the BRICS countries

Cumulative confirmed CovID-19 cases

The number of confirmed cases is lewer than the number of actual cases; the main reason for hiad. is lirniled lesting.

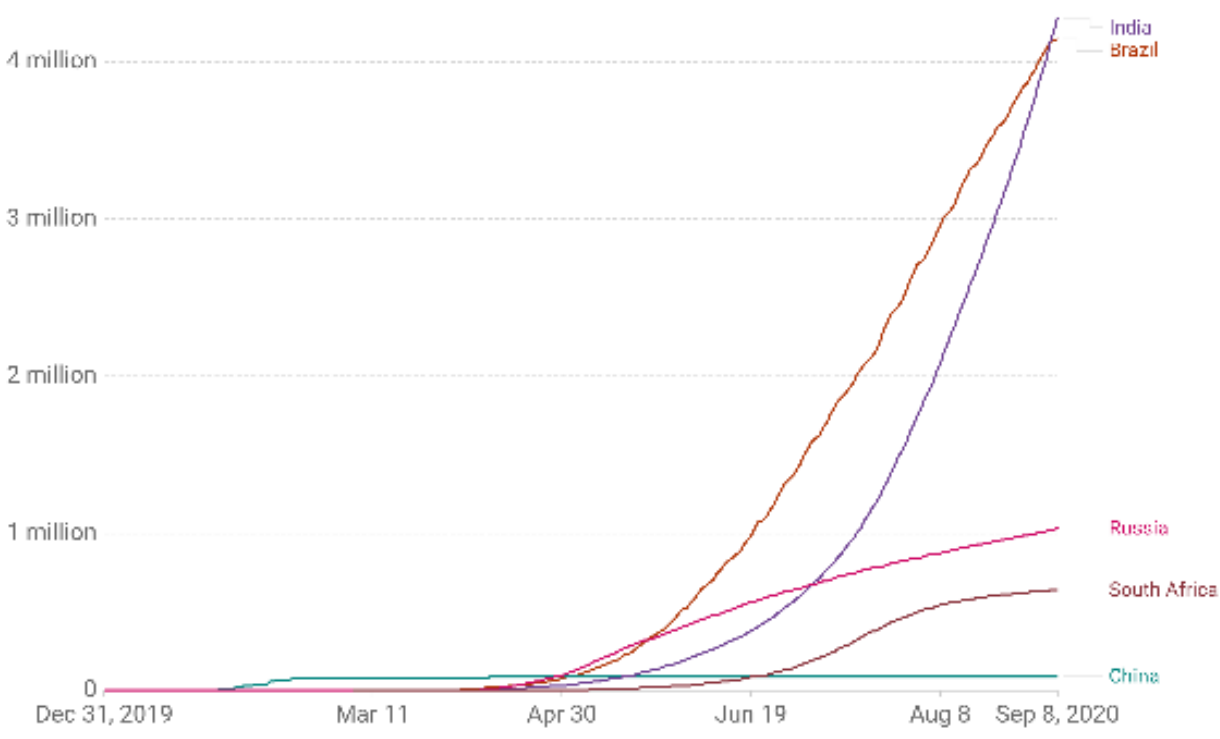

Souros: Eurcpean CuC - Situation Upsate Worlewide - Last u.pdated 8 Srptomber. 12:34 (London tims)

\section{Total confirmed COVID-19 deaths per million people}

Limited testing and challenges in the attribution of the cause of death means that the number of confirmed deaths may not be an accurate count of the true total number of deaths from COVID-19.

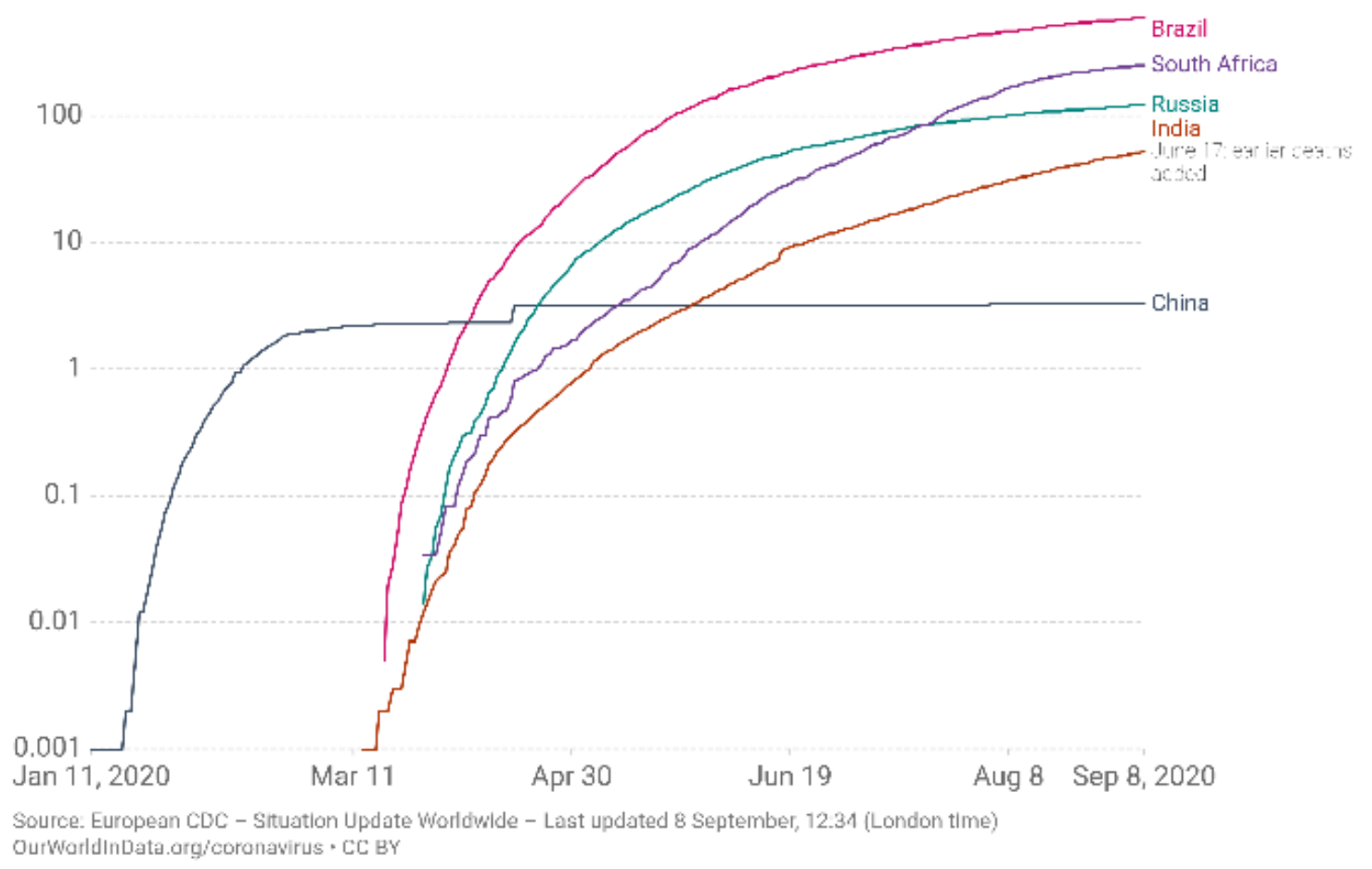

Source: Our World in Data (2020). 


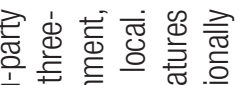

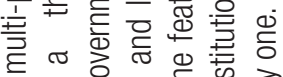

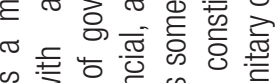
n) ช

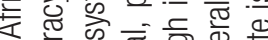
要票

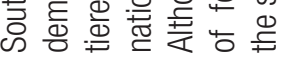

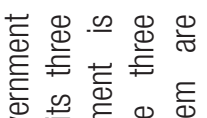

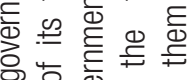

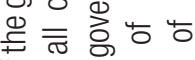

당

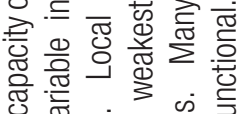

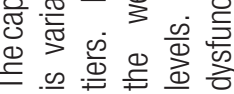

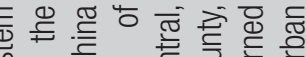

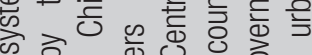
>0

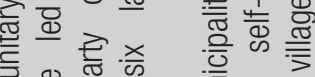
5 응 ๙

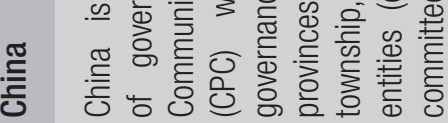
象

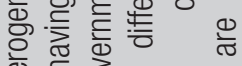

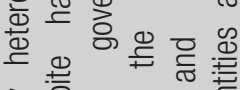
齐

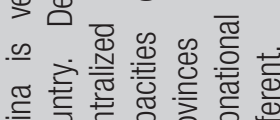

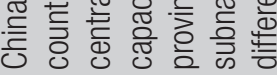

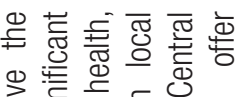

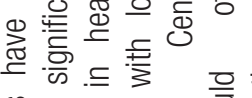

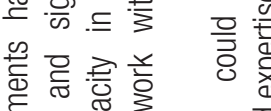

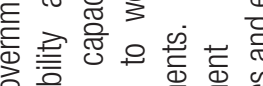
ठे

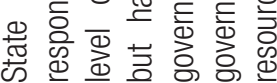

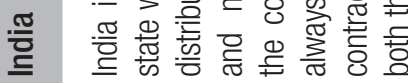

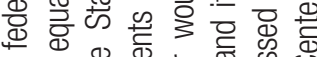
ণ

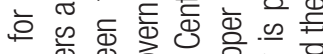

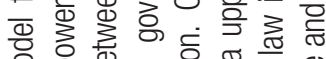

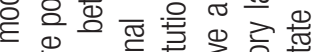

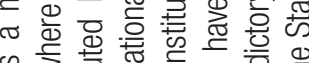

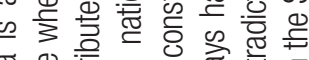

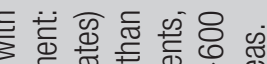
ᄃ है

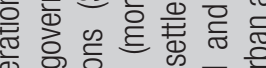

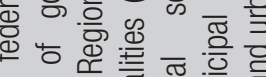
ช

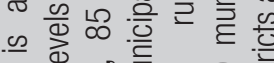

.

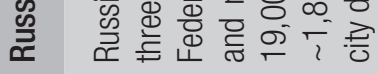

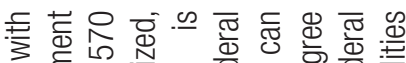

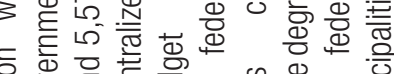
든

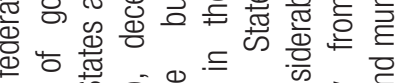
$\sigma \frac{\infty}{\omega} \bar{D}$

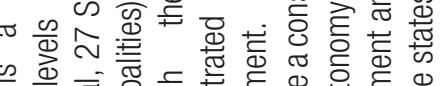

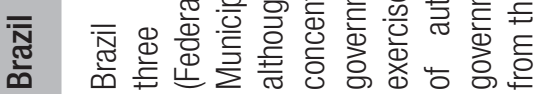

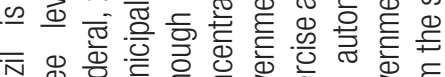

幽

完

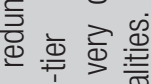

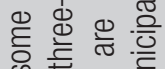

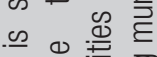

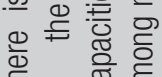
$\stackrel{\Phi}{E} \cong$ 당

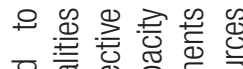

造 응 क्ष

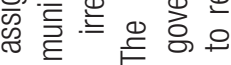

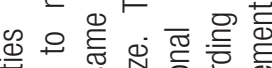

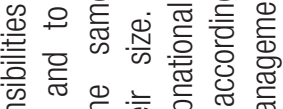

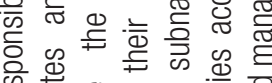

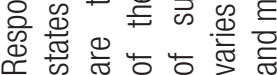

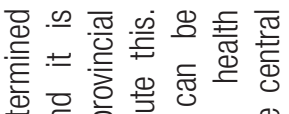

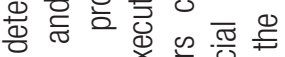

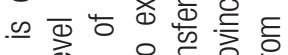

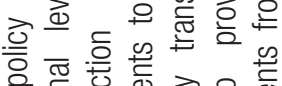

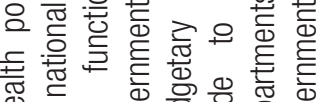

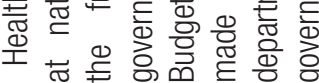

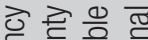

힌 훙 흥 응

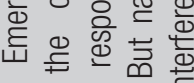

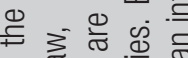
의 잉

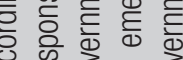

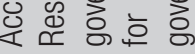

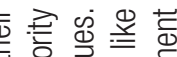

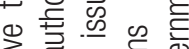

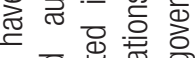

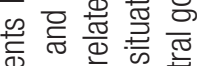

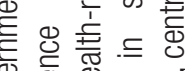

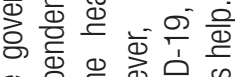
䓌

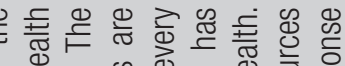

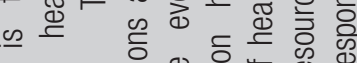

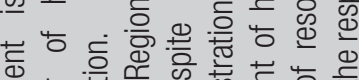
离

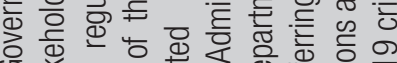

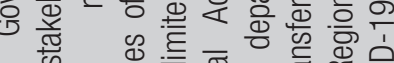

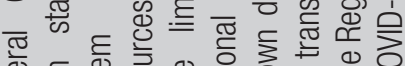

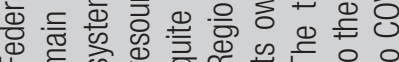
으요

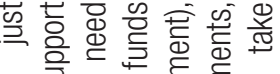
के $\subseteq$ 就 离

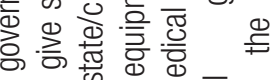

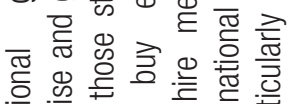

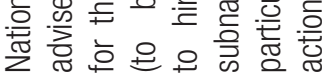

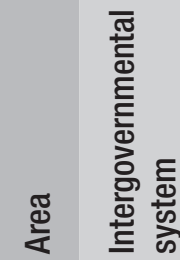

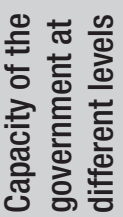

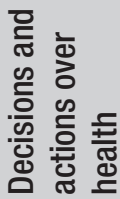

BRAZILIAN JOURNal OF PUblic Administration ｜ Rio de Janeiro 55(1): 243-260, Jan. - Feb. 202 


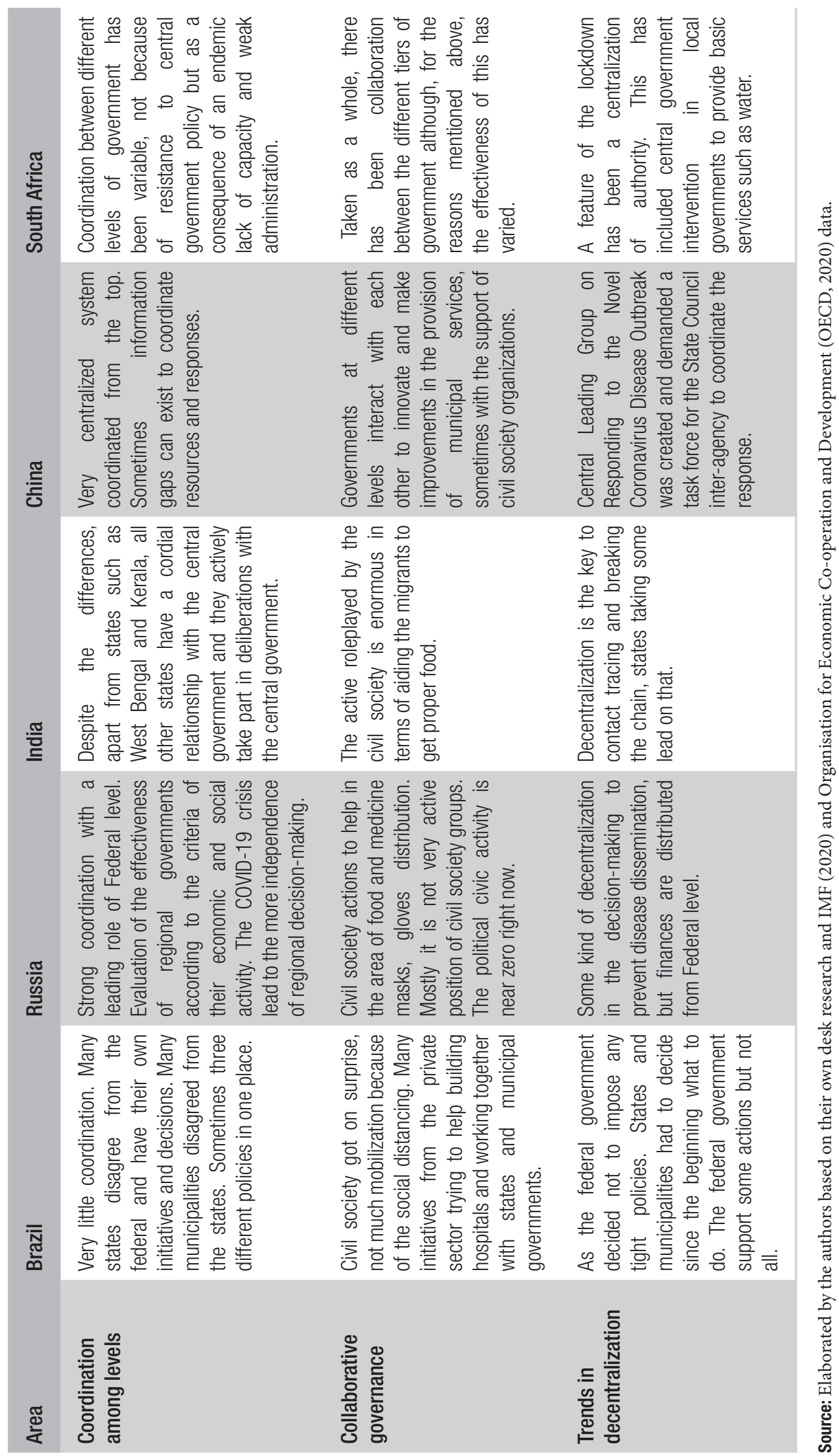

Brazilian Journal of public administration ｜ Rio de Janeiro 55(1): 243-260, Jan. - Feb. 2021 